\title{
SARS-COV-2 IN THE CONTEXT OF CORONAVIRUSES AND ANIMAL MODELS OF COVID-19
}

\author{
Korenkova AA, Bahmetjev W, Gorbunov KS $₫$
}

Federal Research and Clinical Centre of Physical and Chemical Medicine, Federal Medical Biological Agency, Moscow, Russia

\begin{abstract}
Some human coronaviruses that share genetic similarity are known to infect other mammals. A host can harbor several coronaviruses, which creates favorable conditions for recombination and eventually results in the emergence of new viral strains and species. This review looks at SARS-CoV-2 in the context of other coronaviruses and their evolution, with a special focus on possible host jumps and adaptation of the virus to its new hosts. To understand these phenomena, it is essential to know the ecological relationships between the host and other organisms. Candidate COVID-19 models are not limited to the organisms and laboratory animals previously used to study SARS and MERS. The diversity of SARS-CoV-2 hosts suggests there is a wide range of candidate animal models for studying COVID-19 that might be suitable for testing drugs and vaccines against this infection. Considering the diversity of coronaviruses, integrated medical, veterinarian and zoological studies might help to speed up the development of tools for combating coronaviral infections and prevent future epidemics.
\end{abstract}

Keywords: coronavirus, SARS-CoV-2, COVID-19, animal models, viral infections, transmission, epidemic, zoonotic diseases, reservoir

Author contribution: Korenkova AA — data collection, manuscript preparation; Bahmetjev W — data collection, manuscript preparation; Gorbunov KS — supervision.

$\triangle$ Correspondence should be addressed: Konstantin S. Gorbunov

Malaya Pirogovskaya, 1a, Moscow, 119435; konstantin.gorbunov@rcpcm.org

Received: 14.10.2020 Accepted: 11.11.2020 Published online: 28.11.2020

DOI: $10.47183 /$ mes.2020.016

\section{SARS-COV-2 В КОНТЕКСТЕ КОРОНАВИРУСОВ И ЖИВОТНЫЕ МОДЕЛИ ДЛЯ ИЗУЧЕНИЯ COVID-19}

\author{
А. А. Коренькова, В. В. Бахметьев, К. С. Горбунов $\square$ \\ Федеральный научно-клинический центр физико-химической медицины Федерального медико-биологического агентства, Москва, Россия
}

Среди коронавирусов, инфицирующих человека, известен ряд генетически близких видов, поражающих других млекопитающих. В одном организме могут сосуществовать несколько коронавирусов, что создает условия для рекомбинации, приводящей к появлению новых вирусных штаммов и видов. В данном обзоре представлены особенности SARS-CoV-2 в контексте других коронавирусов и их эволюции. Особое внимание уделено возможности перехода коронавируса на новых хозяев и его адаптации, для чего важно понимать экологические связи хозяев с другими живыми существами. Модельными объектами для изучения COVID-19 могут быть не только испытанные на SARS и MERS организмы и популярные лабораторные животные. Разнообразие поражаемых SARS-CoV-2 животных свидетельствует о наличии широкого спектра потенциальных модельных объектов для изучения COVID-19, способных оказаться эффективными при разработке лекарств и вакцин. С учетом разнообразия коронавирусов взаимная интеграция медицинских, ветеринарных и медико-зоологических исследований может ускорить разработку средств борьбы с коронавирусными инсекциями, а также способствовать предупреждению новых эпидемий.

Ключевые слова: коронавирус, SARS-CoV-2, COVID-19, модельные животные, вирусная инфекция, передача вирусов, эпидемия, зооноз, естественный резервуар

Вклад авторов: А. А. Коренькова - сбор информации, написание статьи, редактирование; В. В. Бахметьев - сбор информации, написание статьи; К. С. Горбунов - общее руководство.

$\triangle$ Для корреспонденции: Константин Сергеевич Горбунов

ул. Малая Пироговская, 1а, г. Москва, 119435; konstantin.gorbunov@rcpcm.org

Статья получена: 14.10.2020 Статья принята к печати: 11.11.2020 Опубликована онлайн: 28.11.2020

DOI: 10.47183/mes.2020.016

SARS-CoV-2 is one of the 3 coronaviruses to have caused an epidemic among humans in the 21 st century. Notably, all of those 3 viruses were zoonotic [1]. This underscores the dangers of zoonotic infections to humankind. Coronaviruses have a capacity for recombination and therefore can infect different species. This review looks at SARS-CoV-2 in the context of other coronaviruses that pose a threat to mammals in general and humans in particular. Similar to the studies of SARS-CoV and MERS-CoV, veterinary research of animal coronaviruses, including FCoV (feline infectious peritonitis), CCoV (canine viral enteritis), SADS-CoV (swine acute diarrhea syndrome) and some others, can yield invaluable data for countering SARS-CoV-2.

Developing effective and convenient experimental models of COVID-19 is a pressing concern because animal models are indispensable for studying the pathogenesis of the disease and testing candidate drugs and vaccines.

\section{General characteristics of SARS-COV-2}

An RNA virus that caused the pandemic of 2020 and was termed 2019-nCoV or SARS-CoV-2 is a member of the
Coronaviridae family. Today, 7 Coronaviridae viruses are known to infect humans; of them 3 are associated with acute respiratory syndromes (SARS-CoV, MERS-CoV and SARSCoV-2) and 4 (HCoVs) cause only mild respiratory symptoms (Table 1). According to international reports, all the $4 \mathrm{HCoVs}$ circulate in the human population all year round and are characterized by seasonal incidence peaks [2, 3].

SARS-CoV-2 causes an often asymptomatic disease called COVID-19 [4]. The signs and symptoms observed in patients with mild or moderate COVID-19 remind those of acute respiratory infections and seasonal flu, hampering the diagnosis. Severe COVID-19 can lead to complications, including acute respiratory distress syndrome and multisystem disorders.

The primary route of SARS-CoV-2 transmission is through droplets produced by an infected individual during coughing, sneezing, talking or breathing. This mode of transmission is typically seen in humans and between humans and domestic animals. The novel coronavirus can also spread through fomites, which are objects and surfaces contaminated with biological fluids of infected patients containing viable SARS-CoV-2 
Table 1. Diversity of human coronaviruses

\begin{tabular}{|c|c|c|c|c|c|}
\hline Virus & Genus & Natural reservoir & Intermediate host & Transmission route & Receptor \\
\hline HCoV-229E & \multirow{2}{*}{ Alphacoronavirus } & \multirow{2}{*}{ Bats } & Camels & Droplets/aerosols, fomites & APN \\
\hline HCoV-NL63 & & & Unknown & \multirow{3}{*}{$\begin{array}{l}\text { Droplets/aerosols, direct } \\
\text { contact }\end{array}$} & ACE2 \\
\hline HCoV-OC43 & \multirow{4}{*}{ Betacoronavirus } & \multirow[t]{2}{*}{ Rodents } & Cattle & & $\begin{array}{c}\text { 9-O-acetyl-N- } \\
\text { acetylneuraminic acid }\end{array}$ \\
\hline HCoV-HKU1 & & & Unknown & & \\
\hline MERS-CoV & & \multirow[b]{2}{*}{ Bats } & Camels & & DPP4 \\
\hline SARS-CoV & & & $\begin{array}{c}\text { Palm civets } \\
\text { (Paradoxurus } \\
\text { hermaphroditus) }\end{array}$ & $\begin{array}{l}\text { Droplets/aerosols, direct } \\
\text { contact, fecal-oral route }\end{array}$ & ACE2 \\
\hline
\end{tabular}

virions [5]. It is reported that the pathogen has been detected in wastewater, so it is possible that exposure to contaminated wastewater may result in SARS-CoV-2 infection [6]. Additionally, SARS-CoV-2 RNA has been detected in blood, mucus, saliva, urine, feces [5] and sperm [7. The definitive factor ensuring the spread of the virus through direct contact is its viability outside the host. According to the literature, the reported viability of the novel coronavirus varies from a few hours to a few weeks, depending on the type of contaminated surface and some environmental factors.

The mechanism used by SARS-CoV-2 to invade the host cell is still debatable. There are a few possible entry points, including 2 cell receptors CD147 [8] and GRP78 [9]; however, the dominant cell entry mechanism is through the membrane receptor ACE2 [10]. The S-protein, which forms spikes on the surface of the viral nucleocapsid, anchors to ACE2, and the subsequent cell entry is mediated by the transmembrane serine protease 2 (TMPRSS2) [11]. A similar mechanism is employed by SARS-CoV [12].

ACE2 is expressed in more than 150 different cell types found in almost all human tissues and organs [13], but its expression levels vary depending on the cell type. ACE2 is present on the membranes of type II pneumocytes, small intestine enterocytes, endothelial cells of arteries and veins, and smooth muscle cells of most human organs. Given that SARS-CoV-2 uses ACE2 to enter the cell, one can expect that some signs of COVID-19 will be observed in ACE2-expressing tissue.

\section{Evolution of SARS-COV-2}

It is reported that HCoVs are descended from animal coronaviruses. For example, SARS-CoV, MERS-CoV, HCoVNL63 and HCoV-229E are related to bat coronaviruses, whereas HCoV-OC43 and HKU1, to rodent coronaviruses [1]. SARS-CoV-2 is likely the product of genetic recombination that occurred in a natural reservoir, the Chinese population of bats [14]. The SARS-CoV-2 genome shares $89 \%$ sequence homology with SARS-like-CoVZXC21 and 96\% sequence homology with RaTG13.

Being an RNA virus, SARS-CoV-2 has 2 evolutionary strategies: 1) genetic drift or natural selection of mutations and 2) exchange of genetic material with other viruses through recombination [15]

Between December 2019 and September 2020, over 18,500 SARS-CoV-2 genomes were sequenced. Based on the sequencing data, it was concluded that the novel coronavirus is relatively conserved. This means that future vaccines against SARS-CoV-2 might be equally effective against any of its variants [16]. Most mutations detected in SARS-CoV-2 genome do not affect the properties of the pathogen or reduce its pathogenicity/virulence toward humans. The rate of such mutations, including D614G, can be explained by the founder effect.

Structurally, SARS-CoV-2 is a spherical or pleomorphic enveloped particle containing single-stranded positive-sense RNA. SARS-CoV-2 RNA is complexed with the nucleoprotein inside the viral capsid formed by the matrix protein [17]. The club-shaped spikes of the glycoprotein known as the $S$ protein protrude from the viral envelope. The $S$ protein binds to the membrane of the host cell and mediates the invasion.

Numerous animal studies have demonstrated that coronaviruses frequently undergo genetic recombination. For example, S-protein recombination seems to be a common event in feline and canine coronaviruses [18]. The S-protein is a membrane glycoprotein composed of 2 subunits: S1 and S2. The S1 subunit enables the virion to latch onto the host cell exploiting the interactions between its receptor-binding domain (RBD) and the receptor located on the surface of the host cell. The RBD-encoding gene region is the most variable part of the coronavirus genome. The genetic flexibility of the $\mathrm{S}$ protein and especially its RBD might allow the pathogen to less specifically bind to ACE2 receptors in a variety of animal species and thus expand the range of possible hosts [14]. Mutations in the S protein might induce conformational changes, which, in turn, affects viral antigenicity. So far, a few mutations have been discovered in the $\mathrm{S} 1$ receptor binding region but they have not undermined the ability of the virus to bind to ACE2 in humans, pigs, civets, and bats [19]. Recombination between gene regions coding for the S1 and S2 subunits of the S protein was deemed as one of the major mechanisms facilitating the emergence of human SARS-CoV strains from bat and civet ancestors [20].

Because SARS-CoV-2 is transmitted more rapidly that it evolves, its population is becoming more homogenous, with a median of 7 nucleotide substitutions between genomes. There is evidence of purifying selection, but little data is available to suggest diversifying selection; the rates of nucleotide substitutions are comparable between structural and nonstructural genes [16]. Most mutations acquired by the virus are phenotypic and thus provide information on the geographic and population origin of the viral lineage.

The S protein of SARS-CoV-2 effectively binds to ACE2 receptors in humans, ferrets, cats and other mammals sharing high receptor homology [21]. The remarkable diversity of species susceptible to SARS-CoV-2 suggests that the pathogen can cross the species barrier and encounter other coronaviruses, which might result in a recombination event and thus give birth to novel viral strains and species. In the past 20 years, 3 coronaviruses have spilled over from zoonotic reservoirs; this underscores the need for surveillance of animal coronaviruses [22], the importance of studying mutations that allow zoonotic viruses to perform a host jump and the usefulness of medical zoology research. 
Recombination events among HCoVs have been amply described in the literature [23]. For example, the screening of specimens obtained from Kenyan bats allowed researchers to identify a few viruses exhibiting genetic similarity to HCoV-NL63 and HCoV-229. These viruses were reported to have an eventful history of genetic recombination, including 2 interspecies recombination events involving the S-protein gene. This suggests that the S-protein gene might be a recombination hot spot in coronavirus genomes [24].

\section{Animal coronaviruses are a potential threat to humanity}

Many mammalian coronaviruses have been well studied and characterized by veterinarian scientists. For example, it is known that $\beta$-coronaviruses encompass human viruses $\mathrm{HCOV}-\mathrm{OC} 43$ and HCoV-HKU1 that cause acute respiratory infections in humans and a number of other viruses that infect dogs, cats, cattle, pigs, horses and camels. HCoV-OC43 and bovine BCoV share 95\% sequence homology, whereas SARS-CoV-2 shares almost 96\% sequence homology with RaTG13 (member of the SARSr-CoV group) isolated from the horseshoe bat (Rhinolophus affinis). Viruses genetically close to SARS-CoV-2 have been isolated from other bats and palm civets (Nandinia binotata) [15]. However, although SARS-CoV-2 and bat CoV RaTG13 share almost 98\% homology in the sequences coding for the S protein, the SARS-CoV-2 genome contains an insertion of a furin cleavage site (RRAR) in the S1/S2 region. This multibasic cleavage site might be associated with the high virulence of the novel coronavirus [19]. A virus related to SARS-CoV-2 has been isolated from pangolins (Manis javanica), which is why these animals were thought to be an intermediate host for SARS-CoV-2 [25]. Animal hosts of $\beta$-coronaviruses are potential models of infectious disease caused by this group of viruses, including SARS-CoV-2. Notably, over time intermediate hosts can become natural reservoirs for coronaviruses, whereas viruses predominantly harbored by intermediate hosts can accumulate mutations independently. Besides, in the intermediate host the virus can accumulate mutations allowing it to successfully invade the final host. If the natural host is infected by different populations of the same viral species, recombination between these populations will drive the emergence of new strains [20].

Bats harbor a greater diversity of zoonotic viruses than other mammals [26]. The list of viruses hosted by bats includes relatives of SARS-CoV, MERS-CoV, HCoV-229E, HCoV-NL63 [27], and SARS-CoV-2 [25]. The fact that bats are lowly susceptible to infectious pathology caused by the viruses they host requires thorough investigation. But reports of coronaviruses crossing the species barrier [1] raise the need for close wildlife disease surveillance and research into the potential routes of viral transmission between species, because each host jump increases the odds of a fundamentally new recombination event associated with the virome of the host.

A host can be simultaneously infected with several coronaviruses, which creates favorable conditions for recombination and affects the clinical picture. Coinfections aggravate the course of a primary disease. In human hosts, SARS-CoV-2 can cooccur with other viruses, including coronaviruses that cause respiratory infections [28]. The most common SARS-CoV-2 coinfection is influenza A virus. Respiratory coinfections are negatively correlated with the accuracy of COVID-19 diagnosis, and clinical manifestations of COVID-19 do not always raise suspicions about the presence of another respiratory (viral, bacterial or fungal) pathogen, which may result in the wrong treatment choice.
Unfortunately, coinfections in patients with COVID-19 remain heavily understudied [29]. Coinfection can contribute to the mutability of the coronavirus. Coronaviruses coexisting in one host undergo frequent recombination events and mutate actively [24]. So far, of 39 currently known coronaviruses [30] 7 are capable of infecting humans. These viruses pose a threat to agriculture and human health. Identifying the reservoirs of zoonotic pathogens is crucial to effective disease control and prevention [25].

\section{Animal models of COVID-19}

Animal models are indispensable for conducting preclinical trials of candidate drugs and vaccines and studying the pathogenesis of SARS-CoV-2 infection. Since the clinical manifestations of COVID-19 differ significantly among the infected individuals, it is important to create models reflecting different degrees of disease severity. This will allow researchers to preclinically assess the efficacy of candidate drugs depending on the severity of the disease. Studying the diversity of species that host the virus in question might help to find a suitable animal model. Animals in which the virus replicates but does not cause overt pathology are reservoirs for the infection; their surveillance is critical for preventing the outbreaks of the infection. Animals that can transfer the virus on their skin or fur constitute a separate category. For example, SARS-CoV-2 RNA has been detected in the biological samples of domestic dogs and cats, tigers and lions [15]. However, a positive PCR test does not prove that the tested animal is sick or is the carrier of viable virions. Nevertheless, the fact that the virus can be transmitted from humans to domestic animals is a worrying sign [15], although there were no reports of animal to human transmission.

Initially, the search for animal models of COVID-19 focused on the animals that had been previously regarded as candidate models for SARS and MERS. Unfortunately, none of them were fairly suitable to study these two viruses [31].

Attempts were made to study SARS-CoV replication in Syrian and Chinese hamsters, civets and non-human primates (NHP), such as rhesus monkeys, crab-eating macaques, African green monkeys, etc. [32]. Mice and ferrets were more susceptible to SARS-CoV infection but resistant to MERS-CoV, due to the properties of their DPP4 receptors [25]. Rabbits were not investigated as a potential model of SARS-CoV [31] and turned out to be an unsuitable research model for MERS [33]. A study demonstrated that ferrets (Mustela furo) and domestic cats (Felis domesticus) were susceptible to SARSCoV and could effectively spread the virus to other noninfected animals they were housed with [34]. Likewise, domestic cats and ferrets can be infected with and spread SARS-CoV-2 [35], which makes them a promising SARS-CoV-2 candidate model.

American mink (Neovison vison) bred on fur farms are susceptible to SARS-CoV-2, which they presumably contracted from humans [36]. Thus, mink can be a good animal model for studying COVID-19 and other coronaviruses capable of binding to ACE2. Advantageously, there are well-established housing and care protocols for mink and ferrets. Mink can be used to model severe and moderate COVID-19. However, there are still a few issues related to the housing of these animals in a laboratory environment [37].

Tigers and lions have been reported to develop COVID-19 symptoms [15]. The fact that two distant families of the mammalian order Carnivora, Mustelidae and Felidae, can so easily contract the virus and develop COVID-19 indicates that the wide variety of animal species can act as a reservoir 
Table 2. Model animals

\begin{tabular}{|c|c|c|c|c|c|c|c|c|}
\hline & \multicolumn{2}{|c|}{ Models } & \multicolumn{6}{|c|}{ SARS-CoV-2 } \\
\hline Animal species & SARS & MERS & Symptoms & $\begin{array}{c}\text { Overt } \\
\text { pathology }\end{array}$ & Antibodies & Advantages & Disadvantages & References \\
\hline $\begin{array}{l}\text { Syrian hamster } \\
\text { (Mesocricetus } \\
\text { auratus) }\end{array}$ & Yes & $\begin{array}{l}\text { Does not } \\
\text { replicate }\end{array}$ & Yes & Yes & Yes & $\begin{array}{l}\text { The virus can be passed on from } \\
\text { one animal to another. It replicates } \\
\text { in and causes serious damage to } \\
\text { the lungs, brain, olfactory bulb. } \\
\text { Syrian hamsters produce } \\
\text { antibodies against SARS-CoV-2 } \\
\text { that neutralize the virus in other } \\
\text { infected Syrian hamsters following } \\
\text { convalescent serum transfusion. } \\
\text { The virus is detected in the liver, } \\
\text { kidneys, spleen, heart, intestines, } \\
\text { salivary glands, lymph nodes }\end{array}$ & $\begin{array}{l}\text { Rapid clearance of } \\
\text { the virus. Pathology } \\
\text { was less pronounced } \\
\text { in naturally infected } \\
\text { hamsters than in } \\
\text { the animals with } \\
\text { experimentally induced } \\
\text { infection }\end{array}$ & $\begin{array}{l}{[25,33,} \\
38-40]\end{array}$ \\
\hline $\begin{array}{l}\text { Transgenic mice } \\
\text { with human } \\
\text { hACE2 receptor }\end{array}$ & Yes & $\begin{array}{l}\text { Mice with human } \\
\text { hDPP4 receptor }\end{array}$ & Yes & Yes & Yes & $\begin{array}{l}\text { The virus replicates in the lungs, } \\
\text { causing pneumonia. Inflammation } \\
\text { is moderate }\end{array}$ & $\begin{array}{l}\text { The virus does not } \\
\text { affect other organs; } \\
\text { coagulopathy does not } \\
\text { develop. High costs }\end{array}$ & $\begin{array}{c}{[25,31,33,} \\
41]\end{array}$ \\
\hline $\begin{array}{l}\text { Wild type mice } \\
\text { without human } \\
\text { receptors }\end{array}$ & Yes & No DPP4 & Yes & No & No & No advantages & $\begin{array}{l}\text { Wild type mice are } \\
\text { not susceptible to the } \\
\text { virus. Its replication is } \\
\text { negligible }\end{array}$ & $\begin{array}{c}{[25,31,33} \\
41]\end{array}$ \\
\hline $\begin{array}{l}\text { Domestic cat } \\
\text { (Felis cattus) }\end{array}$ & Yes & $\mathrm{N} / \mathrm{A}$ & Yes & Yes & Yes & $\begin{array}{l}\text { The virus is transmitted among } \\
\text { cats. The virus replicates in the } \\
\text { respiratory tract, tonsils and } \\
\text { intestines. Kittens suffer more } \\
\text { pronounced organ damage }\end{array}$ & $\begin{array}{l}\text { Adult cats are } \\
\text { significantly more } \\
\text { susceptible to the } \\
\text { virus than kittens }\end{array}$ & {$[33,35]$} \\
\hline $\begin{array}{l}\text { Domestic ferret } \\
\text { (Mustela putorius } \\
\text { furo) }\end{array}$ & Yes & $\begin{array}{l}\text { Does not } \\
\text { replicate }\end{array}$ & $\begin{array}{l}\text { In some } \\
\text { ferrets }\end{array}$ & Yes & Yes & Transmission is possible & $\begin{array}{l}\text { The virus replicates in } \\
\text { the upper respiratory } \\
\text { tract and intestines, } \\
\text { but not in the lungs }\end{array}$ & $\begin{array}{c}{[25,31,33,} \\
35,38]\end{array}$ \\
\hline $\begin{array}{l}\text { Domestic dog } \\
\text { (Canis lupus } \\
\text { familiaris) }\end{array}$ & N/A & $\mathrm{N} / \mathrm{A}$ & No & No & $\begin{array}{l}\text { Not in all } \\
\text { cases }\end{array}$ & No advantages & $\begin{array}{l}\text { Low susceptibility to } \\
\text { the virus; } \\
\text { dogs with } \\
\text { experimentally } \\
\text { induced infection do } \\
\text { not transmit the virus } \\
\text { to other dogs }\end{array}$ & [35] \\
\hline $\begin{array}{l}\text { Domestic pig } \\
\text { (Sus scrofa } \\
\text { domesticus) }\end{array}$ & Failed & Failed & No & No & $\begin{array}{l}\text { Conflicting } \\
\text { data }\end{array}$ & No advantages & $\begin{array}{l}\text { Not susceptible to } \\
\text { the virus }\end{array}$ & {$[33,35,37]$} \\
\hline $\begin{array}{l}\text { Crab-eating } \\
\text { macaque } \\
\text { (Macaca } \\
\text { fascicularis) }\end{array}$ & Yes & Yes & Yes & Yes & Yes & $\begin{array}{l}\text { The virus replicates in the lungs and } \\
\text { causes pneumonia }\end{array}$ & $\begin{array}{l}\text { High costs, low } \\
\text { availability, low levels } \\
\text { of viral RNA }\end{array}$ & $\begin{array}{l}{[31,33,38,} \\
42]\end{array}$ \\
\hline $\begin{array}{l}\text { Rhesus monkey } \\
\text { (Macaca mulatta) }\end{array}$ & Yes & Yes & Yes & Yes & Yes & $\begin{array}{l}\text { Increased cytokine expression. } \\
\text { The virus replicates in the lungs and } \\
\text { causes pneumonia. } \\
\text { Viral RNA is detected in the early } \\
\text { stages of the disease in the lungs, } \\
\text { trachea, bronchi, spleen, stomach, } \\
\text { rectum, bladder and uterus }\end{array}$ & $\begin{array}{l}\text { High costs, low } \\
\text { availability }\end{array}$ & {$[31,38,42]$} \\
\hline $\begin{array}{l}\text { Green monkey } \\
\text { (Chlorocebus } \\
\text { sabaeus) }\end{array}$ & Yes & Yes & Yes & Yes & N/A & $\begin{array}{l}\text { A well-established model for many } \\
\text { infectious pathologies. Model } \\
\text { animals develop pneumonia }\end{array}$ & $\begin{array}{l}\text { High costs, } \\
\text { complexity, low } \\
\text { availability. Clinical } \\
\text { manifestations are } \\
\text { very mild }\end{array}$ & {$\left[\begin{array}{c}{[31,33,38,} \\
42]\end{array}\right.$} \\
\hline $\begin{array}{l}\text { Common } \\
\text { marmoset } \\
\text { (Callithrix } \\
\text { jacchus) }\end{array}$ & Yes & Yes & $\begin{array}{l}\text { In some } \\
\text { marmosets }\end{array}$ & No & No & The virus is detected in the blood & $\begin{array}{l}\text { High costs, low } \\
\text { availability. The virus } \\
\text { is not detected in the } \\
\text { lungs and does not } \\
\text { cause pneumonia or } \\
\text { severe lung pathology }\end{array}$ & $\begin{array}{l}{[31,33,38,} \\
42]\end{array}$ \\
\hline
\end{tabular}

Note: N/A - data not available 
for SARS-CoV-2 [34]. It is possible that some of them might become a new effective model for COVID-19. More different mammals need to be investigated in order to identify new potential sources of the infection and find suitable research models. Table 2 describes a few animal models for SARS-CoV-2.

Northern treeshrews (Tupaia belangeri chinensis) and Egyptian fruit bats (Rousettus aegyptiacus) were also investigated as candidate models of SARS-CoV-2 but they did not develop any pathology following a challenge with the coronavirus, although the virus was detected in the multiple organs of these animals [25]. Therefore, the northern treeshrew and the Egyptian fruit bat do not hold promise as COVID-19 models.

The susceptibility of nontransgenic mice to the coronavirus can be significantly affected by their genetic traits unrelated to ACE2 [25], which may skew the clinical picture in a way that cannot be predicted.

Alpacas (Vicugna pacos) and dromedary camels (Camelus dromedarius) were used as the first MERS models [33, 43]. But because the upkeep of dromedary camels is quite challenging and these animals can pass the infection to humans, researchers had to give up the idea of using them as a MERS model. Alpacas infected with MERS-CoV remained clinically healthy although they did produce antibodies [5]. Since there were more convenient animal models, the use of tylopods for studying SARS-CoV-2 was eventually discontinued.

Syrian hamsters turned out to be the most effective and cheap model of COVID-19. Cats and ferrets might hold some promise but their upkeep is more difficult. Despite the absence of data, mink are considered to be a promising model for SARS and MERS. NHP models are vigorously used in preclinical trials of candidate drugs and vaccines against COVID-19.

\section{References}

1. Dhama K, Patel SK, Sharun K, Pathak M, Tiwari R, Yatoo Ml, et al. SARS-CoV-2 jumping the species barrier: Zoonotic lessons from SARS, MERS and recent advances to combat this pandemic virus. Travel Med Infect Dis. 2020 Aug 2; 37: 101830.

2. Killerby ME, Biggs HM, Haynes A, Dahl RM, Mustaquim D, Gerber $\mathrm{SI}$, et al. Human coronavirus circulation in the United States 20142017. J Clin Virol. 2018 Apr; 101: 52-6.

3. Al-Khannaq MN, Takebe Y, Pang YK, Oong XY, Tee KK, Ng KT, et al. Diversity and Evolutionary Histories of Human Coronaviruses NL63 and 229E Associated with Acute Upper Respiratory Tract Symptoms in Kuala Lumpur, Malaysia [Internet]. The American Journal of Tropical Medicine and Hygiene. 2016. 94: 1058-64. Available from: http://dx.doi.org/10.4269/ajtmh.15-0810.

4. Glybochko PV, Fomin W, Avdeev SN, et al. Clinical characteristics of 1007 patients with severe SARS-CoV-2 pneumonia who needed respiratory support [Internet]. Zhurnal Klinicheskaja farmakologija i terapija; 2020 [cited 2020 Sep 23]. Available from: https://clinpharm-journal.ru/articles/2020-2/klinicheskayaharakteristika-1007-bolnyh-tyazheloj-sars-cov-2-pnevmoniejnuzhdavshihsya-v-respiratornoj-podderzhke/.

5. Mohseni AH, Taghinezhad-S S, Xu Z, Fu X. Body fluids may contribute to human-to-human transmission of severe acute respiratory syndrome coronavirus 2: evidence and practical experience. Chin Med. 2020 Jun 5; 15: 58.

6. Lodder W, de Roda Husman AM. SARS-CoV-2 in wastewater: potential health risk, but also data source. Lancet Gastroenterol Hepatol. 2020 Jun; 5 (6): 533-4.

7. Li D, Jin M, Bao P, Zhao W, Zhang S. Clinical Characteristics and Results of Semen Tests Among Men With Coronavirus Disease 2019 [Internet]. JAMA Network Open. 2020; 3: e208292. Available from: http://dx.doi.org/10.1001/jamanetworkopen.2020.8292.

\section{CONCLUSION}

The diversity of coronaviruses poses a serious threat to epidemiologic safety. Future pandemics can be prevented using an integrated approach to medical, veterinarian and zoological studies. In the $20^{\text {th }}$ century, the effective surveillance of zoonotic infections contained the spread of zoonotic viruses from wildlife to humans. Knowing the routes of viral transmission is as important as understanding the coevolution of the virus and its host. Studies of animal coronaviruses might provide invaluable data that will serve as a starting point in researching SARSCoV-2 and other human coronaviruses. Animal models are useful in modeling human diseases, studying the progression of the disease and exploring the properties of the virus. Expanding the range of model animals will allow us to find the optimal models for studying the pathogenesis of COVID-19 and testing candidate drugs and broaden our research potential needed to counter new infections in the future.

Using a systemic biological approach to the analysis of viral diversity and the reconstruction of the interactions between the virus and its host under all possible outcomes, we will be able to effectively contain potential threats and prepare for new pandemics. The human body is an ecosystem, so studies looking into the interactions between the virus and its human host should take into account the interactions between the virus and the human microbiota, as well as the probability of recombination with viruses constituting the human virome. Humans are part of terrestrial ecosystems, so it is important to trace the transmission of the virus from animals to humans and from humans to animals as new mutant viral strains can be passed back from its new host to the human population.
8. Ulrich H, Pillat MM. CD147 as a Target for COVID-19 Treatment: Suggested Effects of Azithromycin and Stem Cell Engagement [Internet]. Stem Cell Reviews and Reports. 2020; 16: 434-40. Available from: http://dx.doi.org/10.1007/s12015-020-09976-7.

9. Ibrahim IM, Abdelmalek DH, Elshahat ME, Elfiky AA. COVID-19 spike-host cell receptor GRP78 binding site prediction. J Infect. 2020 May; 80 (5): 554-62.

10. Vaduganathan M, Vardeny O, Michel T, McMurray JJV, Pfeffer MA, Solomon SD. Renin-Angiotensin-Aldosterone System Inhibitors in Patients with Covid-19. N Engl J Med. 2020 Apr 23; 382 (17): 1653-9.

11. Sanders JM, Monogue ML, Jodlowski TZ, Cutrell JB. Pharmacologic Treatments for Coronavirus Disease 2019 (COVID-19): A Review. JAMA. 2020 May 12; 323 (18): 1824-36.

12. Hoffmann M, Kleine-Weber H, Schroeder S, Krüger N, Herrler T, Erichsen S, et al. SARS-CoV-2 Cell Entry Depends on ACE2 and TMPRSS2 and Is Blocked by a Clinically Proven Protease Inhibitor. Cell. 2020 Apr 16; 181 (2): 271-80.e8.

13. Hikmet F, Méar L, Edvinsson Å, Micke P, Uhlén M, Lindskog C. The protein expression profile of ACE2 in human tissues. Mol Syst Biol. 2020 Jul; 16 (7): e9610.

14. Andersen KG, Rambaut A, Lipkin WI, Holmes EC, Garry RF. The proximal origin of SARS-CoV-2. Nat Med. 2020 Apr; 26 (4): 450-2

15. Leroy $E M, A r$ Gouilh $M$, Brugère-Picoux J. The risk of SARS$\mathrm{CoV}-2$ transmission to pets and other wild and domestic animals strongly mandates a one-health strategy to control the COVID-19 pandemic. One Health. 2020 Apr 13; 100133.

16. Dearlove B, Lewitus E, Bai H, Li Y, Reeves DB, Joyce MG, et al. A SARS-CoV-2 vaccine candidate would likely match all currently circulating variants. Proc Natl Acad Sci U S A [Internet]. 2020 Aug 31; Available from: http://dx.doi.org/10.1073/pnas.2008281117. 
17. Stefanyuk OV, Lazebnik LB. The defeat of the digestive system during infection SARS-CoV-2. Eksp Klin Gastroenterol. 2020 Mar; 175 (3): 4-9.

18. Cui J, Li F, Shi Z-L. Origin and evolution of pathogenic coronaviruses. Nat Rev Microbiol. 2019 Mar; 17 (3): 181-92.

19. Naqvi AAT, Fatima $K$, Mohammad T, Fatima U, Singh IK, Singh A, et al. Insights into SARS-CoV-2 genome, structure, evolution, pathogenesis and therapies: Structural genomics approach. Biochim Biophys Acta Mol Basis Dis. 2020 Oct 1; 1866 (10): 165878

20. Corman VM, Muth D, Niemeyer D, Drosten C. Hosts and Sources of Endemic Human Coronaviruses. Adv Virus Res. 2018 Feb 16; 100: 163-88.

21. Wan Y, Shang J, Graham R, Baric RS, Li F. Receptor Recognition by the Novel Coronavirus from Wuhan: an Analysis Based on Decade-Long Structural Studies of SARS Coronavirus. J Virol [Internet]. 2020 Mar 17; 94 (7). Available from: http://dx.doi. org/10.1128/JVI.00127-20.

22. Tiwari R, Dhama K, Sharun K, lqbal Yatoo M, Malik YS, Singh R, et al. COVID-19: animals, veterinary and zoonotic links. Vet $Q$. 2020 Dec; 40 (1): 169-82

23. Su S, Wong G, Shi W, Liu J, Lai ACK, Zhou J, et al. Epidemiology, Genetic Recombination, and Pathogenesis of Coronaviruses [Internet]. Trends in Microbiology. 2016; 24: 490-502. Available from: http://dx.doi.org/10.1016/j.tim.2016.03.003.

24. Tao Y, Shi M, Chommanard C, Queen K, Zhang J, Markotter W, et al. Surveillance of Bat Coronaviruses in Kenya Identifies Relatives of Human Coronaviruses NL63 and 229E and Their Recombination History. J Virol [Internet]. 2017 Mar 1; 91 (5). Available from: http:// dx.doi.org/10.1128/JVI.01953-16

25. Abdel-Moneim AS, Abdelwhab EM. Evidence for SARS-CoV-2 Infection of Animal Hosts. Pathogens [Internet]. 2020 Jun 30; 9 (7). Available from: http://dx.doi.org/10.3390/pathogens9070529.

26. Olival KJ, Hosseini PR, Zambrana-Torrelio C, Ross N, Bogich TL, Daszak P. Host and viral traits predict zoonotic spillover from mammals. Nature. 2017 Jun 29; 546 (7660): 646-50.

27. Hu B, Ge X, Wang L-F, Shi Z. Bat origin of human coronaviruses. Virol J. 2015 Dec 22; 12: 221.

28. Lansbury L, Lim B, Baskaran V, Lim WS. Co-infections in people with COVID-19: a systematic review and meta-analysis [Internet]. Journal of Infection. 2020; 81: 266-75. Available from: http:// dx.doi.org/10.1016/j.jinf.2020.05.046.

29. Lai C-C, Wang C-Y, Hsueh P-R. Co-infections among patients with COVID-19: The need for combination therapy with non-antiSARS-CoV-2 agents? J Microbiol Immunol Infect. 2020 Aug; 53 (4): 505-12.

30. Coronaviridae Study Group of the International Committee on Taxonomy of Viruses. The species Severe acute respiratory syndrome-related coronavirus: classifying 2019-nCoV and naming it SARS-CoV-2. Nat Microbiol. 2020 Apr; 5 (4): 536-44.

\section{Литература}

1. Dhama K, Patel SK, Sharun K, Pathak M, Tiwari R, Yatoo MI, et al. SARS-CoV-2 jumping the species barrier: Zoonotic lessons from SARS, MERS and recent advances to combat this pandemic virus. Travel Med Infect Dis. 2020 Aug 2; 37: 101830

2. Killerby ME, Biggs HM, Haynes A, Dahl RM, Mustaquim D, Gerber $\mathrm{SI}$, et al. Human coronavirus circulation in the United States 2014 2017. J Clin Virol. 2018 Apr; 101: 52-6.

3. Al-Khannaq MN, Takebe Y, Pang YK, Oong XY, Tee KK, Ng KT, et al. Diversity and Evolutionary Histories of Human Coronaviruses NL63 and 229E Associated with Acute Upper Respiratory Tract Symptoms in Kuala Lumpur, Malaysia [Internet]. The American Journal of Tropical Medicine and Hygiene. 2016. 94: 1058-64. Available from: http://dx.doi.org/10.4269/ajtmh.15-0810.

4. Глыбочко П. В., Фомин В. В., Авдеев С. Н., Моисеев С. В., Яворовский А. Г., Бровко М. Ю. и др. Клиническая характеристика 1007 больных тяжелой SARS-CoV-2 пневмонией, нуждавшихся в респираторной поддержке [Internet]. Журнал Клиническая фармакология и терапия;
31. Gretebeck LM, Subbarao K. Animal models for SARS and MERS coronaviruses [Internet]. Current Opinion in Virology. 2015; 13: 123-9. Available from: http://dx.doi.org/10.1016/j. coviro.2015.06.009.

32. Song Z, Xu Y, Bao L, Zhang L, Yu P, Qu Y, et al. From SARS to MERS, Thrusting Coronaviruses into the Spotlight [Internet] Viruses. 2019; 11: 59. Available from: http://dx.doi.org/10.3390/ v11010059.

33. Singh A, Singh RS, Sarma P, Batra G, Joshi R, Kaur H, et al. A Comprehensive Review of Animal Models for Coronaviruses: SARS-CoV-2, SARS-CoV, and MERS-CoV. Virol Sin. 2020 Jun 35 (3): 290-304.

34. Martina BEE, Haagmans BL, Kuiken T, Fouchier RAM, Rimmelzwaan GF, Van Amerongen G, et al. Virology: SARS virus infection of cats and ferrets. Nature. 2003 Oct 30; 425 (6961): 915.

35. Shi J, Wen Z, Zhong G, Yang H, Wang C, Huang B, et al Susceptibility of ferrets, cats, dogs, and other domesticated animals to SARS-coronavirus 2. Science. 2020 May 29; 368 (6494): 1016-20.

36. Oreshkova N, Molenaar RJ, Vreman S, Harders F, Oude Munnink BB Hakze-van der Honing RW, et al. SARS-CoV-2 infection in farmed minks, the Netherlands, April and May 2020. Euro Surveill [Internet]. 2020 Jun; 25 (23). Available from: http://dx.doi. org/10.2807/1560-7917.ES.2020.25.23.2001005

37. Muñoz-Fontela C, Dowling WE, Funnell SGP, Gsell P-S, Balta XR, Albrecht RA, et al. Animal models for COVID-19. Nature [Internet] 2020 Sep 23; Available from: http://dx.doi.org/10.1038/s41586020-2787-6.

38. Roberts A, Subbarao K. Animal models for SARS. Adv Exp Med Biol. 2006; 581: 463-71.

39. Imai M, Iwatsuki-Horimoto K, Hatta M, Loeber S, Halfmann PJ, Nakajima N, et al. Syrian hamsters as a small animal model for SARS-CoV-2 infection and countermeasure development. Proc Natl Acad Sci USA. 2020 Jul 14; 117 (28): 16587-95.

40. de Wit E, Prescott J, Baseler L, Bushmaker T, Thomas T, Lackemeyer MG, et al. The Middle East respiratory syndrome coronavirus (MERS-CoV) does not replicate in Syrian hamsters PLoS One. 2013 Jul 2; 8 (7): e69127.

41. Bao L, Deng W, Huang B, Gao H, Liu J, Ren L, et al. The pathogenicity of SARS-CoV-2 in hACE2 transgenic mice. Nature. 2020 Jul; 583 (7818): 830-3.

42. Messina F, Giombini E, Agrati C, Vairo F, Ascoli Bartoli T, A Moghazi S, et al. COVID-19: viral-host interactome analyzed by network based-approach model to study pathogenesis of SARSCoV-2 infection. J Transl Med. 2020 Jun 10; 18 (1): 233

43. Crameri G, Durr PA, Klein R, Foord A, Yu M, Riddell S, et al. Experimental Infection and Response to Rechallenge of Alpacas with Middle East Respiratory Syndrome Coronavirus. Emerg Infect Dis. 2016 Jun; 22 (6): 1071-4

2020 [cited 2020 Sep 23]. Available from: https://clinpharmjournal.ru/articles/2020-2/klinicheskaya-harakteristika-1007bolnyh-tyazheloj-sars-cov-2-pnevmoniej-nuzhdavshihsya-vrespiratornoj-podderzhke/.

5. Mohseni AH, Taghinezhad-S S, Xu Z, Fu X. Body fluids may contribute to human-to-human transmission of severe acute respiratory syndrome coronavirus 2: evidence and practical experience. Chin Med. 2020 Jun 5; 15: 58

6. Lodder W, de Roda Husman AM. SARS-CoV-2 in wastewater: potential health risk, but also data source. Lancet Gastroenterol Hepatol. 2020 Jun; 5 (6): 533-4.

7. Li D, Jin M, Bao P, Zhao W, Zhang S. Clinical Characteristics and Results of Semen Tests Among Men With Coronavirus Disease 2019 [Internet]. JAMA Network Open. 2020; 3: e208292. Available from: http://dx.doi.org/10.1001/jamanetworkopen.2020.8292.

8. Ulrich H, Pillat MM. CD147 as a Target for COVID-19 Treatment Suggested Effects of Azithromycin and Stem Cell Engagement [Internet]. Stem Cell Reviews and Reports. 2020; 16: 434-40. 
Available from: http://dx.doi.org/10.1007/s12015-020-09976-7. 9. Ibrahim IM, Abdelmalek DH, Elshahat ME, Elfiky AA. COVID-19 spike-host cell receptor GRP78 binding site prediction. J Infect. 2020 May; 80 (5): 554-62.

10. Vaduganathan M, Vardeny O, Michel T, McMurray JJV, Pfeffer MA, Solomon SD. Renin-Angiotensin-Aldosterone System Inhibitors in Patients with Covid-19. N Engl J Med. 2020 Apr 23; 382 (17): 1653-9.

11. Sanders JM, Monogue ML, Jodlowski TZ, Cutrell JB. Pharmacologic Treatments for Coronavirus Disease 2019 (COVID-19): A Review. JAMA. 2020 May 12; 323 (18): 1824-36.

12. Hoffmann $M$, Kleine-Weber $H$, Schroeder $S$, Krüger N, Herrler T, Erichsen S, et al. SARS-CoV-2 Cell Entry Depends on ACE2 and TMPRSS2 and Is Blocked by a Clinically Proven Protease Inhibitor. Cell. 2020 Apr 16; 181 (2): 271-80.e8.

13. Hikmet F, Méar L, Edvinsson A, Micke P, Uhlén M, Lindskog C. The protein expression profile of ACE2 in human tissues. Mol Syst Biol. 2020 Jul; 16 (7): e9610.

14. Andersen KG, Rambaut A, Lipkin WI, Holmes EC, Garry RF. The proximal origin of SARS-CoV-2. Nat Med. 2020 Apr; 26 (4): 450-2.

15. Leroy EM, Ar Gouilh M, Brugère-Picoux J. The risk of SARSCoV-2 transmission to pets and other wild and domestic animals strongly mandates a one-health strategy to control the COVID-19 pandemic. One Health. 2020 Apr 13; 100133.

16. Dearlove B, Lewitus E, Bai H, Li Y, Reeves DB, Joyce MG, et al. A SARS-CoV-2 vaccine candidate would likely match all currently circulating variants. Proc Natl Acad Sci U S A [Internet]. 2020 Aug 31; Available from: http://dx.doi.org/10.1073/pnas.2008281117.

17. Stefanyuk OV, Lazebnik LB. The defeat of the digestive system during infection SARS-CoV-2. Eksp Klin Gastroenterol. 2020 Mar; 175 (3): 4-9.

18. Cui J, Li F, Shi Z-L. Origin and evolution of pathogenic coronaviruses. Nat Rev Microbiol. 2019 Mar; 17 (3): 181-92.

19. Naqvi AAT, Fatima K, Mohammad T, Fatima U, Singh IK, Singh A, et al. Insights into SARS-CoV-2 genome, structure, evolution, pathogenesis and therapies: Structural genomics approach. Biochim Biophys Acta Mol Basis Dis. 2020 Oct 1; 1866 (10): 165878.

20. Corman VM, Muth D, Niemeyer D, Drosten C. Hosts and Sources of Endemic Human Coronaviruses. Adv Virus Res. 2018 Feb 16; 100: 163-88.

21. Wan Y, Shang J, Graham R, Baric RS, Li F. Receptor Recognition by the Novel Coronavirus from Wuhan: an Analysis Based on Decade-Long Structural Studies of SARS Coronavirus. J Virol [Internet]. 2020 Mar 17; 94 (7). Available from: http://dx.doi. org/10.1128/JVI.00127-20

22. Tiwari R, Dhama K, Sharun K, lqbal Yatoo M, Malik YS, Singh R, et al. COVID-19: animals, veterinary and zoonotic links. Vet $\mathrm{Q}$. 2020 Dec; 40 (1): 169-82.

23. Su S, Wong G, Shi W, Liu J, Lai ACK, Zhou J, et al. Epidemiology, Genetic Recombination, and Pathogenesis of Coronaviruses [Internet]. Trends in Microbiology. 2016; 24: 490-502. Available from: http://dx.doi.org/10.1016/j.tim.2016.03.003.

24. Tao Y, Shi M, Chommanard C, Queen K, Zhang J, Markotter W, et al. Surveillance of Bat Coronaviruses in Kenya Identifies Relatives of Human Coronaviruses NL63 and 229E and Their Recombination History. J Virol [lnternet]. 2017 Mar 1; 91 (5). Available from: http:// dx.doi.org/10.1128/JVI.01953-16.

25. Abdel-Moneim AS, Abdelwhab EM. Evidence for SARS-CoV-2 Infection of Animal Hosts. Pathogens [Internet]. 2020 Jun 30; 9 (7). Available from: http://dx.doi.org/10.3390/pathogens9070529.

26. Olival KJ, Hosseini PR, Zambrana-Torrelio C, Ross N, Bogich TL, Daszak P. Host and viral traits predict zoonotic spillover from mammals. Nature. 2017 Jun 29; 546 (7660): 646-50.
27. Hu B, Ge X, Wang L-F, Shi Z. Bat origin of human coronaviruses. Virol J. 2015 Dec 22; 12: 221.

28. Lansbury L, Lim B, Baskaran V, Lim WS. Co-infections in people with COVID-19: a systematic review and meta-analysis [Internet]. Journal of Infection. 2020; 81: 266-75. Available from: http:// dx.doi.org/10.1016/j.jinf.2020.05.046.

29. Lai C-C, Wang C-Y, Hsueh P-R. Co-infections among patients with COVID-19: The need for combination therapy with non-antiSARS-CoV-2 agents? J Microbiol Immunol Infect. 2020 Aug; 53 (4): 505-12.

30. Coronaviridae Study Group of the International Committee on Taxonomy of Viruses. The species Severe acute respiratory syndrome-related coronavirus: classifying 2019-nCoV and naming it SARS-CoV-2. Nat Microbiol. 2020 Apr; 5 (4): 536-44.

31. Gretebeck LM, Subbarao K. Animal models for SARS and MERS coronaviruses [Internet]. Current Opinion in Virology. 2015; 13: 123-9. Available from: http://dx.doi.org/10.1016/j. coviro.2015.06.009.

32. Song $Z, X u Y$, Bao $L$, Zhang $L, Y u P, Q u$, et al. From SARS to MERS, Thrusting Coronaviruses into the Spotlight [Internet]. Viruses. 2019; 11: 59. Available from: http://dx.doi.org/10.3390/ v11010059.

33. Singh A, Singh RS, Sarma P, Batra G, Joshi R, Kaur $H$, et al. A Comprehensive Review of Animal Models for Coronaviruses: SARS-CoV-2, SARS-CoV, and MERS-CoV. Virol Sin. 2020 Jun; 35 (3): 290-304.

34. Martina BEE, Haagmans BL, Kuiken T, Fouchier RAM, Rimmelzwaan GF, Van Amerongen G, et al. Virology: SARS virus infection of cats and ferrets. Nature. 2003 Oct 30; 425 (6961): 915.

35. Shi J, Wen Z, Zhong G, Yang H, Wang C, Huang B, et al. Susceptibility of ferrets, cats, dogs, and other domesticated animals to SARS-coronavirus 2. Science. 2020 May 29; 368 (6494): 1016-20.

36. Oreshkova N, Molenaar RJ, Vreman S, Harders F, Oude Munnink BB, Hakze-van der Honing RW, et al. SARS-CoV-2 infection in farmed minks, the Netherlands, April and May 2020. Euro Surveill [Internet]. 2020 Jun; 25 (23). Available from: http://dx.doi. org/10.2807/1560-7917.ES.2020.25.23.2001005.

37. Muñoz-Fontela C, Dowling WE, Funnell SGP, Gsell P-S, Balta XR, Albrecht RA, et al. Animal models for COVID-19. Nature [Internet]. 2020 Sep 23; Available from: http://dx.doi.org/10.1038/s41586020-2787-6.

38. Roberts A, Subbarao K. Animal models for SARS. Adv Exp Med Biol. 2006; 581: 463-71.

39. Imai M, Iwatsuki-Horimoto K, Hatta M, Loeber S, Halfmann PJ, Nakajima N, et al. Syrian hamsters as a small animal model for SARS-CoV-2 infection and countermeasure development. Proc Natl Acad Sci USA. 2020 Jul 14; 117 (28): 16587-95.

40. de Wit E, Prescott J, Baseler L, Bushmaker T, Thomas T, Lackemeyer MG, et al. The Middle East respiratory syndrome coronavirus (MERS-CoV) does not replicate in Syrian hamsters. PLoS One. 2013 Jul 2; 8 (7): e69127.

41. Bao L, Deng W, Huang B, Gao H, Liu J, Ren L, et al. The pathogenicity of SARS-CoV-2 in hACE2 transgenic mice. Nature. 2020 Jul; 583 (7818): 830-3.

42. Messina F, Giombini E, Agrati C, Vairo F, Ascoli Bartoli T, A Moghazi S, et al. COVID-19: viral-host interactome analyzed by network based-approach model to study pathogenesis of SARSCoV-2 infection. J Transl Med. 2020 Jun 10; 18 (1): 233.

43. Crameri G, Durr PA, Klein R, Foord A, Yu M, Riddell S, et al. Experimental Infection and Response to Rechallenge of Alpacas with Middle East Respiratory Syndrome Coronavirus. Emerg Infect Dis. 2016 Jun; 22 (6): 1071-4. 